\title{
TRANSFERABILITY OF TAX INCENTIVES AND THE FICTION OF SAFE HARBOR LEASING
}

\author{
Alvin C. Warren, Jr. ${ }^{*}$ and Alan J. Auerbach ${ }^{* *}$
}

Safe harbor leasing has been heralded as a method to transfer the benefits of the investment tax credit and accelerated depreciation to firms that pay little or no income tax, and thereby to equalize the ability of taxpaying and nontaxpaying firms to obtain these benefits. Professors Warren and Auerbach argue, however, that although there are a number of ways to define this kind of "competitive neutrality," the fictional leases required by current law implement none of those definitions. In addition, they argue that the fiction of leasing has undesirable collateral consequences that need not accompany a program of transferability of tax benefits.

$\mathrm{T}$ The Economic Recovery Tax Act of I98I introduced a federal income tax "safe harbor" for leasing transactions in order to distribute the benefits of the investment tax credit (ITC) and the newly enacted Accelerated Cost Recovery System (ACRS) throughout the corporate sector. ${ }^{1}$ Although less than a year has passed since adoption of the I98I Act, there is already considerable Congressional support for alteration or repeal of the leasing provisions. ${ }^{2}$

This Article evaluates safe harbor leasing as a means of accomplishing the transfer of tax incentives. The focus here is not whether ACRS and the ITC are themselves desirable, but whether, given these provisions, the new rules for tax leasing are necessary and appropriate. ${ }^{3}$ We conclude that a

* Professor of Law, Harvard University. Yale University, B.A., I966; University of Chicago, J.D., I 969 .

** Assistant Professor of Economics, Harvard University. Yale University, B.A., I974; Harvard University, $\mathrm{Ph} . \mathrm{D}$., 1978.

1 S. REP. No. 144,97 th Cong., ist Sess. 61-63 [hereinafter cited as SENATE REPORT], reprinted in I98I U.S. CODE CONG. \& AD. NEWS I66-67. The safe harbor is found in $\S I 68(f)(8)$ of the Internal Revenue Code and was enacted in title II, \$ 201 (a) of the Economic Recovery Tax Act of r98I, Pub. L. No. 97-34, 95 Stat. 172, 203. The provision constitutes a "safe harbor," because satisfying the terms of $\S \mathrm{I} 68(\mathrm{f})(8)$ precludes the government from arguing on other grounds that a transaction should not be considered a lease. See infra pp. 1762-63.

2 For example, Senator Robert Dole, Chairman of the Senate Finance Committee, announced on February I9, I982, that he would seek to repeal or alter the safe harbor retroactive to February 20, 1982. See Business Tax Cut Affecting Leasing Appears Near End, N.Y. Times, Feb. 20, I982, at I, col. 4.

3 For an evaluation of ACRS, see Auerbach, The New Economics of Accelerated Depreciation, B.C.L. REv. (forthcoming 1982). The details of safe harbor leasing transactions are discussed in Koffey, Safe Harbor Leasing, U. S. CAL. TAX INST. (forthcoming 1982). 
program of transferability or refundability ${ }^{4}$ may be justified for ACRS deductions and the ITC, but that safe harbor leasing is inadequate as a method of effecting transferability.

The Article examines six topics: (I) the purpose and benefits of ACRS and the ITC; (2) the case for extending these benefits to companies without substantial taxable income; (3) the amount of benefits transferred by safe harbor leasing; (4) the amount that should be transferred, given the purpose of the provisions; (5) problems created by adoption of the leasing mechanism rather than an explicit program of transferability; and (6) conclusions for tax policy. This Article also includes a mathematical Appendix that sets forth the formal analysis underlying the discussion of topics (3) and (4).

\section{The Investment Tax Credit and the Accelerated Cost Recovery SYSTEM}

Adherence to the concept of income requires that the cost of an asset with a limited lifetime be deducted from the revenues produced by the asset over its useful life. In theory, these depreciation deductions, or capital costs, should match "economic depreciation" - the actual decline in value of the asset - as closely as possible. ${ }^{5}$ But to encourage investment, the Internal Revenue Code explicitly deviated from this principle in two significant ways before the I98I Act was adopted. First, the Code granted an investment tax credit for purchases of qualified property, which could be described loosely as machinery and equipment. 6 Second, the rate of depreciation was increased, and the depreciable life decreased, for certain assets; these changes resulted in faster recovery of capital costs for tax purposes than would have been consistent with economic depreciation. ${ }^{7}$

\footnotetext{
4 "Refundability" generally refers to a program under which the government would pay, or refund, the cash value of a deduction or a credit to taxpayers with no taxable income against which to use the deduction or no tax liability against which to use the credit. See, e.g., Campisano \& Romano, Recouping Losses: The Case for Full Loss Offsets, $76 \mathrm{NW}$. U.L. REv. 709,7 II-I5 (I98I) (arguing for refundability of net operating losses).

5 Deductibility of economic depreciation not only conforms to the definition of income, but also leaves investor choices among assets unaffected by the income tax. See Samuelson, Tax Deductibility of Economic Depreciation to Insure Invariant Valuations, 72 J. POL. ECON. 604 (1964).

${ }^{6}$ See I.R.C. $\$ \$ 46,48$ (Supp. III I979). Property eligible for the ITC is denominated "section 38 property," see id. $\$ 46(a)(2)$, and is defined in $\$ 48$.

7 Id. \$ 167 (1976); Treas. Reg. \$.'1.167(a)-12 (1977); Rev. Proc. 77-1o, I977-I C.B. 548; Rev. Proc. 72-10, 1972-1 C.B. 721.
} 
The r98I Act extended this deviation from economic depreciation by further disassociating the period over which an asset's cost is recovered from the asset's actual useful life. ${ }^{8}$ The Act divided all depreciable assets into four categories of "recovery property," with each category determining the period over which an asset's cost may be deducted. ${ }^{9}$ These periods are generally shorter than either actual economic lifetimes or the depreciation lives under prior law. ${ }^{10}$ The explicitly articulated rationale for these changes was to stimulate investment necessary for economic expansion, as well as to simplify the tax law. ${ }^{11}$

The value of the new system to purchasers of eligible property is considerable. Perhaps the easiest way to demonstrate the significance of the change is to compare the present value (in the year in which the recovery property is purchased) of the tax savings that will result from future ACRS deductions and the ITC with the present value of the tax burden associated with income produced by the property involved. For example, at a discount rate of twelve percent and a corporate tax rate of forty-six percent, $\$$ Ioo of five-year property (which includes most industrial machinery and equipment) generates tax savings with a present value of $\$ 46.65 .12$ For the marginal

${ }^{8}$ As if to emphasize this change, Congress substituted ACRS deductions, which were referred to in the legislative history as "cost recovery allowances," for depreciation deductions. See I.R.C. $\$$ I67(a) (West Supp. I982); SENATE REPORT, supra note $I$, at $6 \mathrm{I}-62$.

9 Assets are assigned to recovery classes with 3-, 5-, ro-, or 15-year recovery periods by I.R.C. § $168(c)(2)$ (West Supp. I982).

10 Compare, e.g., I.R.C. \& I68 (West Supp. 1982) with Treas. Reg. I.167(a)-I2 (1977) and Rev. Proc. 72-10, I972-I C.B. 721, and Rev. Proc. 77-10, 1977-I C.B. 548.

11 SENATE REPORT, supra note $\mathrm{I}$, at 47.

12 Assuming that the property is purchased for $\$ 100$ on the last day of year one and that the tax benefits for that year are immediately available, the present value of the I0\% ITC, see I.R.C. \& 46(a)(2) (Supp. III I979), is \$10. The rounded present value of the ACRS deductions, as computed below, is $\$ 79.68$, which generates $\$ 36.65$ in tax savings when the tax rate is $46 \%(.46 \times \$ 79.68=\$ 36.65)$. Thus, the present value of the combined tax benefits is $\$ 46.65$ ( $\$ 10+\$ 36.65)$.

TABLE I

Present Value of ACRS Deductions

\begin{tabular}{lccc}
\hline \hline Year & $\begin{array}{c}\text { I } \\
\text { Discount Factor } \\
(@)_{\text {I2\% })}\end{array}$ & $\begin{array}{c}2 \\
\text { ACRS Deductions }\end{array}$ & $\begin{array}{c}3 \\
\text { Present Value } \\
{[(\mathbf{I}) \times(2)]}\end{array}$ \\
\hline I & $\mathbf{1 . 0 0 0}$ & 15 & 15.00 \\
2 & .893 & 22 & 19.64 \\
3 & .797 & 21 & 16.74 \\
4 & .712 & $2 \mathrm{I}$ & 14.95 \\
5 & .636 & 21 & 13.35 \\
Total & & I00 & 79.68 \\
\hline \hline
\end{tabular}


investment, the $\$ 100$ cost is the present value of all future cash flows to be produced by the asset; ${ }^{13}$ hence the present value of the tax burden on those flows, at a tax rate of fortysix percent, is $\$ 46$. A comparison of that burden with the $\$ 46.65$ tax savings shows that there is no net income tax associated with income produced by the five-year property. Calculations such as this have led to statements, even by Treasury officials, that the I98I Act reduced to zero the effective tax rate on income from certain capital investments. ${ }^{14}$

In this example, the combined value of ACRS deductions and the ITC roughly equals the value of an immediate deduction for the entire cost of the equipment. ${ }^{15}$ As is well known, deducting (or, as it is sometimes called, "expensing") a capital cost has the effect of eliminating the tax burden on the taxpayer's investment, because the tax savings from the deduction will fund all future taxes on income produced by the investment. ${ }^{16}$ Under expensing (or in our ACRS/ITC example), the government in effect becomes the investor's partner by con-

The present value will be greater for property placed in service after 1984 , because ACRS deductions will be more accelerated. See id. \$ 168(b)(I) (West Supp. 1982). The foregoing computations would, of course, change if the discount rate were other than $12 \%$. The Appendix includes examples based on a $15 \%$ discount rate.

13 The price of the marginal investment in an asset will generally equal the present value of the investment's future cash flows, because a greater present value would lead investors to divert resources into purchase of such an asset and thereby bid up its price. Conversely, if the present value were smaller, investors would make other more profitable investments and thereby drive down the price of the asset.

Because the tax consequences of the capital recovery allowances and the income stream are calculated separately in the example, there is no need to reduce the cash flow by depreciation. The example assumes that all receipts will be taxed as ordinary income at the rate of $46 \%$.

14 "In effect, we've eliminated the tax on income from investment in equipment, and we've also greatly expanded the opportunities for leasing plant and equipment by making it possible to transfer some tax benefits." Remarks by Donald T. Regan, Secretary of the Treasury, at the Twelfth Congressional District Business Conference (Oct. 14, 1981) (on file in Harvard Law School Library).

15 The value of a full deduction for \$100 worth of equipment is $\$ 46$ when the tax rate is $46 \%$. The House Ways and Means Committee adopted a full deduction for certain capital expenditures during its consideration of what became the Economic Recovery Tax Act of I98r. See H.R. REP. No. 20I, 97th Cong., Ist Sess. 73-74 (I981).

${ }^{16}$ A $50 \%$ taxpayer with other income would, for example, be indifferent between (I) investing \$roo in a perpetuity yielding an exempt return of ro\% annually, and (2) investing $\$ 200$ in a deductible perpetuity (with the tax savings from the deduction providing the additional $\$ 100)$ yielding a taxable return of Io\% annually. Both investments would produce $\$ 10$ annually after taxes. The equivalence between expensing and exemption, which was first identified in Brown, Business-Income Taxation and Investment Incentives, in INCOME, EMPLOYMENT AND PUBlic Policy 300 , 309-10 (1948), assumes that a taxpayer's tax rate remains constant. See generally $\mathrm{R}$. Musgrave, The Theory of Public Finance 262, 266-67 (1959) (discussing effects of tax rates on savings and consumption). 
tributing forty-six percent of the asset's cost in exchange for a forty-six percent share of the profits. This zero effective tax rate on capital income and the Treasury's participation in the investment distinguish a (cash flow) consumption or expenditure tax from an income tax. ${ }^{17}$

There is, however, nothing inherently limiting about a zero tax rate under ACRS and the ITC. Several studies have suggested that for some industries and some assets the effective rate of tax will actually be negative as a result of the I98I Act. ${ }^{18}$ Indeed, the tax is somewhat negative in our example: the present value of tax benefits $(\$ 46.65)$ exceeds the present value of future tax liabilities $(\$ 46)$ by sixty-five cents.

Before turning to the problems that were created by these provisions and for which leasing was adopted as a solution, we should identify an ambiguity in the rationale for ACRS and the ITC, for it is an ambiguity that may affect evaluation of the safe harbor. In brief, the ITC and ACRS provisions can be seen either as structural components of the income tax that reduce the effective tax rate or as government subsidies that are located in the Internal Revenue Code merely as a matter of convenience.

Under the first of these views, Congress may have intended to reduce the effective rate of taxation on certain capital investments on the theory that capital income taxation reduces after-tax return on investment and therefore discourages investment. This theory is, of course, the essence of much of the argument against taxing income from capital as opposed to income from labor. ${ }^{19}$ The after-tax return on investment is reduced further by the failure of the income tax to adjust capital recovery provisions for inflation, a failure that creates additional distortions among assets with different lifetimes. ${ }^{20}$ In our ACRS/ITC example, the rough equivalence of expected tax benefits and burdens would eliminate any deviations between expected pretax and after-tax return. As a result, the

17 See generally INSTITUTe for Fiscal Studies, The STRUCTURE AND REForm of Direct TAXation 33-38 (1978) [hereinafter cited as MEADE REPORT]; Andrews, A Consumption-Type or Cash Flow Personal Income Tax, 87 HARV. L. Rev. III3, Ir 26-28, II5I-53 (1974) (discussing the impact of personal income and consumption taxes on capital investment).

18 E.g., U.S. President, Economic Report of the President 123-24 (1982); Auerbach, supra note 3 .

${ }^{19}$ See, e.g., Boskin, Taxation, Saving, and the Rate of Interest, 86 J. PoL. Econ. $\mathrm{S}_{3}, \mathrm{~S}_{18-S_{25}}$ (1978); Feldstein, The Welfare Cost of Capital Income Taxation, $86 \mathrm{~J}$. Pol. ECon. S29 (r978).

${ }^{20}$ See, e.g., Auerbach, Inflation and the Choice of Asset Life, 87 J. PoL. ECoN. 621 (1979); Feldstein \& Summers, Inflation and the Taxation of Capital Income in the Corporate Sector, 32 NAT'L TAX J. 445 (1979). 
capital income tax would no longer have the distorting effects attributed to it.

If ACRS and the ITC were intended simply to eliminate or reduce a positive tax rate, the lower limit of effective tax rates should be zero. Accordingly, even taxpayers for whom there remains a positive or zero rate of tax on income from recovery property should not be permitted a full deduction for interest payments related to acquisition of recovery property. ${ }^{21}$ To exempt or tax income from an investment at a reduced rate while allowing a full deduction for interest payments may permit taxpayers to achieve negative effective tax rates, even when ACRS deductions and the ITC alone would not achieve such rates. ${ }^{22}$

Under the alternative explanation for ACRS and the ITC, the possibility of negative effective tax rates is not even rele-

$21 \mathrm{~A}$ requirement of consistency between income and deduction items to prevent coupling of less than full taxation of income with full deductibility for expenses is familiar, but not universal, under the income tax: investors cannot deduct interest payments on indebtedness incurred to carry tax-exempt bonds, I.R.C. $\$ 265(2)$ (West Supp. 1982); only a limited amount of investment interest can be deducted from ordinary income by individuals; $i d . \S_{163}$ (d) (1976), and prior cost recovery allowances must be recaptured as ordinary income on the disposition of certain capital assets, id. $\$ \$ 168,1245(\mathrm{a})(2)(\mathrm{E}), \mathrm{I} 245(\mathrm{a})(5), 1250$ (West Supp. I 982 ). The requirement is also a familiar one in the theoretical literature, with most proponents of consumption taxation advocating either inclusion of borrowed funds in the tax base or nondeductibility of interest if the cost of an asset is to be deductible or its return exempt. See MEADE REPORT, supra note 17, at 175-82; Andrews, supra note 17, at 1153-55; Graetz, Implementing a Progressive Consumption Tax, 92 HARV. L. REv. 1575, I609-I I (r979). On this view, continued unlimited deductibility of interest in the face of effective deductibility for assets under ACRS and the ITC is excessive if the goal is simply reduction of the burden of capital income taxation.

22 Borrowing $\$ 100$ at 10\% to invest in a tax-exempt perpetuity yielding $10 \%$ would produce no pretax income, but an annual after-tax return of $\$ 4.60$ to a $46 \%$ taxpayer, because the interest expense is deductible from other income. Borrowing at $10 \%$ to make a deductible investment in a perpetuity yielding a taxable return of $10 \%$ would produce the same result: by borrowing $\$ 100$, the investor could purchase $\$ 185.19$ of the deductible asset, with the additional $\$ 85$. I 9 provided by tax savings resulting from the deduction $(\$ 85.19=.46 \times \$ 185.19)$. Each year the investor would receive $\$ 18.52$ from the asset (.IO $\times \$ 185.19)$, pay the lender \$IO (.IO $\times$ \$100), and retain $\$ 4.60$ after paying taxes of $\$ 3.92(.46 \times(\$ 18.52-\$ 10))$.

Nonetheless, the advantage of using offsetting transactions in this way - often called tax arbitrage - may diminish over time. Differential taxation of capital assets is generally thought to lead to differences in pretax return, because the capital markets will seek to equate after-tax return (adjusted for risk). Otherwise, investors would shift to assets producing a higher after-tax return. Hence as more investment is made in a tax-favored asset, or as the tax benefit is capitalized, the pretax return on the favored assets should fall relative to the pretax return on fully taxable assets. Given adequate capital markets, tax arbitrage is, in this case, simply a phenomenon of disequilibrium. See Bradford, The Economics of Tax Policy toward Savings, in THE Government and Capital Formation i , 43-44 (G. von Furstenberg ed. I980). 
vant to tax policy, for ACRS and the ITC are not a part of the tax system at all. Rather, they constitute an expenditure program by which the government intends to reduce the price of recovery property in order to encourage its purchase, capital formation, and the economic benefits that are thought to ensue. The ITC involves a subsidy to the extent of the tax credit plus the additional deductions obtained, because the asset's basis need not be reduced by the tax credit. ${ }^{23}$ ACRS also creates a subsidy because the present value of the ACRS deductions exceeds the present value of economic depreciation. The ACRS subsidy can be viewed as an interest-free loan, under which the government makes available in earlier years the tax reductions investors would have obtained by deducting economic depreciation in later years. Under this explanation for ACRS and the ITC, continued deductibility of interest is required to define taxable income properly, quite apart from the subsidy, which appears on the tax return only as a matter of convenience.

Unfortunately, the legislative history does not indicate which of these two views of ACRS and the ITC represents the intent of Congress. The relevant committee report speaks both of the effect of reductions in the real value of depreciation deductions on the profitability of investment and of "stimulating capital formation, increasing productivity and improving the nation's competitiveness in international trade" 24 - language that is consistent with either perspective.

\section{The Case for Extending the Benefits of ACRS} aNd THE ITC to Companies Without TaXable Income

ACRS deductions and the ITC are valuable only if a taxpayer has taxable income against which the deductions can be taken and tax liability against which the ITC can be credited. There are, however, at least two types of taxpayers that do not meet these conditions.

\section{A. Start-Up Companies}

A company that purchases recovery property and has no other income or expenses (a "start-up company") generally has

23 If a taxpayer pays $\$$ Ioo for an asset and receives an ITC of \$Io, the taxpayer's net cost is reduced to $\$ 90$, but the asset's basis for depreciation remains $\$ 100$. See I.R.C. $\$$ I68(b)(I), (d) (West Supp. I982).

24 Senate RePort, supra note $I$, at 47 . The President's 1983 budget declines to classify ACRS as a tax subsidy, on the ground that ACRS is now the general cost recovery system of the income tax. U.S. Budget, Special Analysis G, 6-7 (Fiscal Year I983). 
ACRS deductions and ITC in the initial years that exceed the income and tax liability produced by the property. For example, five-year property purchased at the end of a taxable year must produce income in excess of eighty percent of the asset's cost to absorb ACRS deductions and ITC available during the following twenty-four months. ${ }^{25}$ When ACRS is fully phased in after 1985 , the required income will increase to $100 \%$ of the asset's cost. Thus, unless the recovery property produces large amounts of income in its early years, a start-up company does not receive the same present value of tax benefits as does a "profitable company" that can apply ACRS deductions against current income and the ITC against taxes on income from other assets. Even unlimited carryover of deductions and credits would not put a start-up company in the same position as a profitable company, because the profitable company would receive its benefits earlier than would the start-up company. ${ }^{26}$

If ACRS and the ITC are to provide equivalent benefits to corporations investing equivalent amounts in the same categories of recovery property, some mechanism is needed to equate the tax benefits received by a start-up company with those received by a profitable company. Whether the combined effect of ACRS and the ITC is thought of as a form of tax reduction or as an investment subsidy, the desirability of equivalent benefits can be justified on two grounds. ${ }^{27}$ First,

25 The ACRS deductions for the first three years total $58 \%(15+22+2 \mathrm{I})$, and an additional $22 \%$ is required to produce enough income to absorb the ITC ( $22 \times$ $.46=10$ ) if the $90 \%$ ceiling in I.R.C. $\$ 46(\mathrm{a})(3)(B)$ (Supp. III I979) is ignored. If the limitation is taken into account, but its inapplicability to the first $\$ 25,000$ of $\operatorname{tax}$ liability is ignored, the required amount increases from $80 \%$ to $82.15 \%$, because income in the amount of $24.15 \%$ of the asset's cost is required to absorb the 10\% ITC $(24.15 \times .46 \times .9=10)$. After 1985 , the ACRS deductions total $76 \%(20+32+$ 24); thus, the required income is $100.15 \%$ of the asset's cost, calculated in the same way $(76+24 \cdot 15)$.

${ }^{26}$ The I98 I Act extended the carryover for net operating losses from 7 to 15 years.

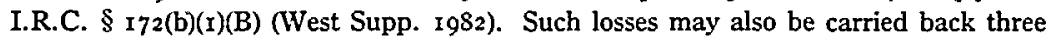
years. A similar carryback and carryover for the unused portion of the ITC is provided by $\$ 46(b)$.

${ }^{27}$ See U.S. PRESIDENT, supra note I8, at 125-26(I982); Chapoton, A Clarification of the New Rules for Tax Leasing, Wall St. J., Dec. 8, I98I, at 34, col. 3; Statement of John E. Chapoton, Assistant Secretary of the Treasury for Tax Policy, Before the Subcommittee on Oversight of the House Committee on Ways and Means (Dec. 15, 1981) (on file in Harvard Law School Library); Statement of John E. Chapoton, Assistant Secretary of the Treasury for Tax Policy, Before the Senate Finance Committee (Dec. 10, 198I) (on file in Harvard Law School Library) [hereinafter cited as Senate Statement of John E. Chapoton]; Statement of Frederic W. Hickman Before the Subcommittee on Oversight of the House Committee on Ways and Means (Dec. I5, I98I) (on file in Harvard Law School Library); Statement of Emil M. Sunley 
to avoid economic distortions, the government should be neutral among potential investors in similar projects. Second, nonneutrality might stimulate tax-induced mergers of profitable and start-up companies. For example, a profitable retail company that owned little recovery property might merge with a start-up company so that the latter's ACRS deductions and ITC could be used to reduce the former's tax liability. We will refer generally to both grounds for extending the benefits of ACRS and the ITC as arguments to further "competitive neutrality." 28

\section{B. Loss Companies}

A second category of taxpayers that would not fully benefit from ACRS deductions and the ITC without some additional mechanism consists of corporations that have operating losses, net operating loss carryovers, or other tax attributes that immunize them from taxation in the foreseeable future. Such corporations will be called, rather loosely, "loss companies." Although loss companies were apparently the intended beneficiaries of safe harbor leasing as much as were start-up companies, the Treasury has generally used a hypothetical startup company in post-enactment illustrations of how the safe harbor operates. ${ }^{29}$ To be sure, a loss company (like a start-up company) represents an extreme case, but the discussion that follows applies to other corporations to the extent they cannot use ACRS deductions and the ITC.

If the purpose of ACRS and the ITC is to reduce capital income taxation, loss companies should not be included among the beneficiaries of those provisions, because such companies are already effectively exempt. If, however, ACRS and the ITC are considered subsidies rather than a means of reducing capital income taxation, 30 the principle of competitive neutrality supports extending these subsidies to loss companies for

Before the Subcommittee on Oversight of the House Committee on Ways and Means (Dec. $1_{5}, 198 \mathrm{r}$ ) (on file in Harvard Law School Library).

28 For a more complete discussion of the concept of "competitive neutrality," see infra pp. I768-72.

29 See, e.g., Senate Statement of John E. Chapoton, supra note 27.

30 Given that the combined effect of ACRS deductions, the ITC, and interest deductibility may permit even profitable companies to achieve negative effective rates of taxation with respect to certain assets, a policy of equivalent tax reduction for equivalent investment in the same category of recovery property might suggest that loss companies should also be able to achieve a less-than-zero effective rate of tax. At this point, the tax reduction rationale for ACRS and the ITC becomes indistinguishable from the subsidy rationale. 
the same two reasons that it supports extension to start-up companies. First, payment of capital subsidies for investment in equipment by some companies but not by others may decrease economic welfare if the subsidized companies are not those best able to make the most socially desirable investments. This rationale is arguably subject to the objection that some loss companies may not be profitable because they are poorly managed, and therefore should not be subsidized. This objection assumes that competitive market pressures will fail to improve management and that government action is therefore necessary. If, however, the economy is basically competitive, it will provide incentives to minimize poor management and to eliminate the need for differential government subsidies. ${ }^{31}$

The second argument for extending the subsidy to loss companies is that otherwise they may merge with profitable companies to obtain the subsidy. Although it is difficult to know precisely how much merger activity might occur, restricting the subsidies to companies with taxable income and tax liabilities would surely result in increased pressure for conglomeration. There is no reason to suppose that such mergers, which would not be attractive to the parties in the absence of tax incentives, would be beneficial to the economy. Nor will all tax-induced mergers be deterred by the prospect of consolidating with an unprofitable company. Loss companies include not only economically unprofitable corporations, but also successful corporations that have no taxable income or tax liability for whatever reason, including the use of tax incentives.

\section{Summary}

The combined effect of ACRS deductions and the ITC can be justified either as a reduction of capital income taxation or as an investment subsidy that has only a coincidental connection with the tax system. Under the former view, negative effective tax rates make continued availability of full deductions for interest payments inappropriate. Under either view, start-up companies should receive the benefits of ACRS deductions and the ITC to achieve either the same tax reduction or the same investment subsidy that profitable companies re-

31 An additional objection to neutral subsidies is the general proposition that the existence of other tax-induced distortions makes it difficult to demonstrate that any new distortions reduce economic welfare, but economic theory suggests that this proposition is not applicable here. See, e.g., Auerbach, Tax Nentrality and The Social Discount Rate, J. PUB. EcoN. (forthcoming); Diamond \& Mirrlees, Optimal Taxation and Public Production I: Production Efficiency, 6I AM. EcoN. Rev. 8, I7-20 (I97I). 
ceive. Extension of these benefits to loss companies requires acceptance of the subsidy rationale.

Unfortunately, the assumptions regarding these provisions are not articulated well enough in the legislative history to support a clear conclusion about what was intended. Congress simply indicated that the benefits of ACRS deductions and the ITC should be available to loss and start-up companies, but not to exempt organizations or, with one exception, to governmental units. ${ }^{32}$ Moreover, the concept of competitive neutrality is not precise enough to suggest just what quantum of benefits should be available to loss and start-up companies. Before attempting to give some greater content to that concept, we turn to an examination of the benefits that are available under the new leasing provisions.

\section{The Benefits of Safe Harbor Leasing}

Although a variety of leasing arrangements are permissible under the $198 \mathrm{I}$ provisions, in this Article we concentrate on the sale-leaseback transaction, both because it is the purest form of transferability under the safe harbor and because this type of transaction has been used by the Treasury in its illustrations of how safe harbor leasing operates. In a typical saleleaseback, the buyer of tax benefits (the "lessor") purchases an asset from the seller (the "lessee") and leases the property back to the seller for use in the lessee's business. This transaction need be a sale only for federal income tax purposes; no attribute of ownership need pass to the lessor under local law. Ownership status for the lessor and characterization of the transaction as a lease are thus fictitious - the relationship between the parties need have none of the characteristics of a true lessor/lessee relationship.

These provisions represent a significant deviation from the traditional dominance of substance over form in determining ownership for tax purposes. ${ }^{33}$ Although leveraged leases were used to transfer the ITC and accelerated depreciation before the I98I Act, transfer of these tax benefits, which are attri-

32 Certain mass commuting vehicles financed with tax-exempt bonds are "qualified leasing property" under the special rule of I.R.C. $\S$ I68(f)(8)(D)(iii) (West Supp. I982). I.R.C. $\S 48(\mathrm{a})(4)-(5)$ (1976) prevents other property used by tax-exempt organizations and government units from qualifying as section 38 property eligible for the ITC and, therefore, as qualified leasing property under $\S$ I68(f)(8)(D). Accordingly, the benefits of ACRS, but not those of the ITC, can be transferred by leasing such vehicles.

33 The deviation is recognized in STAFF of THE JoINT CoMm. ON TAX'N, 97TH Cong., ist Sess., General Explanation of the Economic Tax Recovery ACT of I98I, at ro4 (Comm. Print I98I). 
butes of ownership, required the transfer of sufficient nontax ownership rights to the lessor. ${ }^{34}$ To facilitate transfer of the benefits of ACRS and the ITC, the I98I Act separated what the regulations refer to as "federal tax ownership" 35 from ownership for all other purposes. The fictional ownership status of the lessor thus exists only as a means of transferring tax benefits.

With the transaction cast in the form of a sale, the lessor's cash payment to the lessee for tax benefits is characterized as a down payment on the purchase price. The remainder of the purchase price is financed by a "loan" from the lessee to the lessor. The lessor repays this loan over the term of the lease with principal and interest payments that just equal the rental payments from the lessee to the lessor; thus, the down payment is the only cash to change hands. The lease will nonetheless produce tax consequences. In addition to ACRS deductions and the ITC, the lessor will deduct interest payments and include rental income, while the lessee will deduct rental payments and include interest income.

Because the principal and interest payments are structured to equal rental payments, the lessor's taxable income from the lease (apart from ACRS deductions) is equivalent to the principal payments (rental income minus interest payments) on the fictional loan. Income is thereby returned in the future in accordance with the rate of amortization of the loan. Although the loan principal equals the purchase price of the recovery

${ }^{34}$ Before the Ig8I Act, the Internal Revenue Service had issued guidelines indicating when it would rule that a transaction would be characterized as a lease for tax purposes. A putative lessor would be considered the owner of property only if the lessor possessed certain attributes of ownership, including a $20 \%$ minimum at-risk investment, a positive cash flow, and a pretax profit from the investment. The lessee could possess neither the right to purchase the property at less than fair market value nor an investment in the lease. The use of the property at the end of the lease term by someone other than the lessee had to be commercially feasible. Rev. Proc. 76-30, x976-2 C.B. 647; Rev. Proc. 75-28, 1975-1 C.B. 752; Rev. Proc. 75-2 I, 1975-1 C.B. 715. For a criticism of such ownership criteria on the ground that differences between long-term leases and purchases are not matters of substance, see Note, "Safe Harbor" as Tax Reform: Taxpayer Election of Lease Treatment, 95 HARv. L. REv. 1648, I65763 (1982).

The guidelines regarding substantive nontax ownership attributes are abrogated for safe harbor leases by I.R.C $\$ 168(f)(8)(C)$ (West Supp. I982). If the parties elect to characterize their transaction as a lease, only the following factors may be considered in determining whether the transaction is a lease: (I) the lessor must be a corporation, partnership of corporations, or grantor trust involving corporations; (2) it must maintain a ro\% at-risk investment; and (3) the term of the lease must not exceed the greater of $90 \%$ of the useful life of the the property or $150 \%$ of the preI98I class life for depreciation purposes. I.R.C $\$$ I68(f)(8)(B)(ii) (West Supp. I g82).

${ }^{35}$ Temp. Treas. Reg. $\S 5$ c.68(f)(8)-I(c) (I98I). 
property minus the down payment, the sum of ACRS deductions equals the full purchase price. Thus, over the term of the lease, the lessor's deductions exceed its inclusions by the amount of the down payment. Because the down payment is the payment for tax benefits, safe harbor leasing accordingly results in the effective deductibility of payments for tax benefits, a consequence that raises the question whether the appropriate amount of benefits is being transferred to the lessee when the effect of the deduction is taken into account. We return to this question after using an example to illustrate the operation of a safe harbor sale-leaseback.

A lessor will be willing to make a down payment equal to the present value of tax reductions resulting from ACRS deductions and the ITC, minus the present value of taxes resulting from future inclusions in income (payments of principal under the loan). That amount can be easily calculated for each dollar invested by the lessee in recovery property by the following formula:

$$
d=k+t\left[P V_{A C R S}\right]-t\left[P V_{p}\right](\mathrm{I}-d),
$$

where $d$ is the portion of the cost represented by the down payment, $k$ the rate of ITC, $t$ the tax rate, $\left[P V_{A C R S}\right]$ the present value of the ACRS deductions per dollar invested in recovery property, and $\left[P V_{p}\right]$ the present value of the principal payments on a one dollar loan. ${ }^{36}$ Unlike the terms of a true lessor-lessee relationship, the terms of the lease do not depend on the actual return produced by the asset, a return that does not appear in the formula.

Because we know the value of $k$ (.I) and that of $t(.46)$, we can solve the equation for the down payment if we also know the discount rate (which we shall assume to be twelve percent after taxes), the amortization rate for ACRS deductions (which is in the Internal Revenue Code), and the amortization rate for the outstanding principal (which depends on the interest rate and term of the loan). The present value of the ACRS deductions for one dollar of five-year property is $\$ .7968$ when the discount rate is twelve percent, ${ }^{37}$ while the present value of principal payments on a one dollar loan amortized with level annual payments of principal and interest over eight years at twelve percent is $\$ .5807 .{ }^{38}$ Given these values, the

${ }^{36}$ In the interest of simplicity, the computation ignores any trivial amount the lessee must pay the lessor at the end of the lease term to acquire the recovery property. A similar expression is found in Sunley, The Analytics of Safe-Harbor Leases, I3 TAX Notes I2I9 (I98I).

37 See supra note 12.

38 Indebtedness of one dollar would be amortized over eight years with level 
down payment can be calculated in accordance with the formula set out above:

$$
\begin{aligned}
d & =. I+(.46)(.7968)-(.46)(.5807)(I-d) \\
& =.272
\end{aligned}
$$

If the lessor pays the lessee $\$ 27.20$ as a down payment for $\$$ roo of five-year property, the lessor will receive an immediate ITC of ten dollars, plus ACRS deductions with a net present value, after subtracting the future additions to taxable income required by the lease, of $\$ 37.40$. Given a tax rate of forty-six percent, the present value of the tax savings that result from the net deductions is $\$ 17.20(.46 \times \$ 37.40)$, and the lessor has thus received just what it paid for: tax benefits with a present value of $\$ 27.20$ ( $\$ 10+\$ 17.20)$. Since the discount rate is twelve percent, the lessor has earned an after-tax return of twelve percent on its investment of $\$ 27.20 .^{39}$ The calculation of the net present value of the lessor's ACRS deductions and rental income (after subtracting interest) is as follows:

annual payments of principal and interest of $\$ .2013$ in accordance with the following schedule:

TABLE II

AMORTIZATION OF \$I LOAN AT 12\% INTEREST OVER EIGHT Years

\begin{tabular}{lccc}
\hline \hline Year & Loan Balance & Interest Payment & Principal Payment \\
\hline 2 & 1.000 & .1200 & .0813 \\
3 & .9187 & .1102 & .0911 \\
4 & .8276 & .0993 & .1020 \\
5 & .7256 & .0871 & .1142 \\
6 & .6114 & .0734 & .1279 \\
7 & .4835 & .0580 & .1433 \\
8 & .3402 & .0408 & .1605 \\
9 & .1797 & .0216 & .1797 \\
\hline \hline
\end{tabular}

The present value of the principal payments can be computed by summing the products of each year's principal payment (shown in Table II) and each year's discount factor (shown in Table I, see supra note 12 ). As in the computation in Table I, the example assumes that the property is purchased on the last day of year one and that the first principal payment is therefore due on the last day of year two.

39 The pattern of cash flows, as shown in Table III, see infra p. 1766, for the lessor - cash outflow (the down payment), followed by cash inflow (net tax savings), followed by cash outflow (net tax payments) - results in the existence of a second internal rate of return under which the down payment just equals the present value of the after-tax cash flow. As in the case of tax shelters displaying this pattern of cash flows, taxpayers sometimes attempt to avoid the existence of two (equally accurate) rates of return by assuming that part of the cash inflow is invested in a sinking fund at a specified rate of return to fund the later cash outflow. See, e.g., Krane, Economic Analysis of Tax Sheltered Investments, 54 TAxes 806 (I976); Miller \& Moody, Quantitative Techniques in Financial Decision-Making for Taxes, 59 Taxes $831,839-40(\mathrm{rg8I})$. This assumption results in a single rate of return for the remaining cash flows, but that rate is merely an artifact of the assumed rate of return on the sinking fund and does not provide a reliable guide to investment decisions. 
TABLE III

ACRS Deductions and Net Income Under Safe Harbor LEASING

\begin{tabular}{lcccc}
\hline \hline Year & $\begin{array}{c}\text { ACRS } \\
\text { Deductions }\end{array}$ & $\begin{array}{c}\text { Rent } \\
\text { Minus } \\
\text { Interest40 }\end{array}$ & $\begin{array}{c}\text { Net } \\
\text { Taxable } \\
\text { Income }\end{array}$ & $\begin{array}{c}\text { Present } \\
\text { Value of Net } \\
\text { Taxable Income }\end{array}$ \\
\hline 1 & $(15)$ & - & $(15.00)$ & $(15.00)$ \\
2 & $(22)$ & 5.92 & $(16.08)$ & $(14.36)$ \\
3 & $(21)$ & 6.63 & $(14.37)$ & $(11.46)$ \\
4 & $(21)$ & 7.43 & $(13.57)$ & $(9.66)$ \\
5 & $(21)$ & 8.31 & $(12.69)$ & $(8.06)$ \\
6 & 0 & 9.31 & 9.31 & 5.28 \\
7 & 0 & 10.43 & 10.43 & 5.28 \\
8 & 0 & 11.68 & 11.68 & 5.28 \\
9 & 0 & 13.08 & 13.08 & 5.28 \\
Total & $(100)$ & 72.80 & $(27.20)$ & $(37.40)$ \\
\hline \hline
\end{tabular}

As Table III indicates, the lessor has obtained ACRS deductions of $\$ 100$, but must include only $\$ 72.80$ in income. In effect, the lessor deducts its $\$ 27.20$ payment to the lessee over the term of the lease as the excess of depreciation over net income from the sale-leaseback. The lessee correspondingly includes $\$ 27.20$ more in income than it would have done if the tax benefits had not been transferred to the lessor. ${ }^{42}$ If, however, the lessee can use an otherwise expiring net operating loss carryover or other tax attribute to offset this additional income, the Treasury's revenue loss from the lessor's deduction will not be offset by a corresponding gain from the lessee's inclusion.

The foregoing example of a safe harbor lease is but one example of the amount a lessor would pay a lessee. As the formula indicates, this amount will vary in accordance with the term of the lease, the interest and amortization rates on the note, and the discount rate used to evaluate cash flows. Moreover, the lessor will presumably pay less than the full value of the tax benefits to obtain a fee for its services, in-

40 These amounts are the principal payments due on a $\$ 72.80$ loan and are based on the principal payments required for a one dollar loan shown in Table II, see supra note 38 .

41 The discount factors used to compute present value are those shown in Table I, see supra note 12 . The column does not total precisely, because of rounding.

42 In the example in the text, the lessee would have net deductions (rental payments minus interest receipts) of $\$ 72.80$. Had the lessee not entered into a lease, it would have had ACRS deductions of $\$ 100$; thus, one effect of the lease is to require the inclusion of an additional $\$ 27.20$ in the lessee's income over the term of the lease. 
cluding any risks it takes, although competition among profitable companies seeking to become lessors should reduce the amount of the fee. ${ }^{43}$ But whatever price is agreed upon, the lessor will, in effect, be able to deduct its payment for the transferred tax benefits as long as the sale-leaseback format is followed.

Although effective deductibility of the payment for tax incentives is a characteristic of the sale-leaseback, the Treasury has declined to authorize certain transactions involving the sale of the ITC alone (that is, transactions in which ACRS deductions are not also transferred), apparently because the lessor can deduct its payment for the ITC and thereby magnify the tax benefits transferred to the lessee. 44 In such a transaction, usually called an "ITC strip" or a "lease-leaseback," the user might lease $\$$ Ioo worth of equipment to a buyer of tax benefits for rent of, say, $\$ 90$, with the buyer then leasing the equipment back to the user for a rent of, say, $\$ 80$ over the same term, with the ITC allocated to the buyer. ${ }^{45}$ The buyer of tax benefits thus receives not only the ITC of \$1o, but also a deduction for $\$$ ro, because the net payment in that amount is characterized as rent expense. If the buyer's tax rate is forty-six percent and the ITC is available immediately, the buyer would then be willing to increase its net payment for the ITC up to $\$ \mathrm{I} 8.52$. It is not obvious, however, that this result is inappropriate: profitable companies are not required to reduce the ACRS basis of eligible property by the amount of the ITC ${ }^{46}$ and thus are able to deduct not only their own costs for the recovery property, but also the amount of the ITC. Arguably, therefore, the Treasury should authorize lease-leasebacks; at the least, lessees should also benefit from some form of ITC deductibility, perhaps over the ACRS lifetime of the asset.

Having identified the purpose of safe-harbor leasing and the amount transferred in a sale-leaseback, we now consider whether the benefits of safe harbor leasing, including the effective deductibility of the down payment, are consistent with its purpose.

43 Preliminary estimates of the commissions retained by lessors have varied. The Treasury Department, for example, has concluded that $84 \%$ of the benefits of safe harbor leasing passed through to lessees in 1981. See Preliminary Report on Safe Harbor Leasing Activity in 1981 , I5 TAX Notes 85 (1982).

${ }_{44}$ Temp. Treas. Reg. $\$ 5$ c.I68(f)(8)-9 (I98I) (reserved).

45 I.R.C. \$ 48 (d) (Supp. III 1979) permits allocation of the ITC to a lessee under certain circumstances.

46 See supra note 23 (discussing basis). 


\section{What Amount of Tax Incentives Should Be TRANSFERABLE OR REFUNDABLE?}

If the premise of safe harbor leasing - that competitive neutrality requires extension of tax incentives to start-up and loss companies - is accepted, then a program of refundability, ${ }^{47}$ explicit transferability, or leasing requires articulation of the amount of benefits to be refunded or transferred. There are numerous possibilities, none of which leads to the results identified above for leasing. This Part examines some of the possibilities with respect to loss companies.

\section{A. Equal Costs of Capital}

First, the goal of transferability could be to leave loss and profitable companies in a position of true competitive equality by equalizing their after-tax costs of capital for investments in the same assets. ${ }^{48}$ This goal suggests not only that loss companies should benefit from ACRS deductions and the ITC to the same extent as profitable companies, but also that they should benefit from interest deductibility to the same extent as profitable companies. Profitable companies can fully deduct interest payments, even though in a period of inflation a portion of what is denominated interest may, in fact, be repayment of capital.

Under a program of refundability that involved a single payment by the Treasury to loss companies, the government would have to calculate the amount that would equalize costs of capital between profitable and unprofitable firms. ${ }^{49}$ Leasing or any other form of transferability should result in a payment by the profitable company to the loss company in the same amount. Using the formula set forth above, the Appendix calculates, as examples, the down payments under five-year and ten-year safe harbor leases for assets that qualify as fiveyear recovery property and decline in value at the rate of ten and fifteen percent annually; the interest rate is assumed to be fifteen percent. The Appendix also derives expressions for the single payment that would be necessary to equate the user cost of capital on such assets held by profitable and loss companies,

47 See supra note 4 (defining refundability).

48 The Staff of the Joint Committee on Taxation suggests that ACRS was "intended in part to provide loss companies with the same cost of capital as other firms." Staff of the Joint Comm. on Tax'n, Safe Harbor Leasing Provisions Under Accelerated Cost Recovery System, Daily Tax Rep. (BNA) No. 205, Oct. 23, I981, at J-7, J-8.

${ }^{49}$ Refundability might also be accomplished by a series of payments over a portion of the asset's lifetime. 
and calculates the results when the inflation rate is eight percent and profitable companies are assumed to finance with debt at the margin. As indicated by the following table, the amounts received by loss companies from profitable companies under safe harbor leasing are significantly less than the amounts required to achieve equality of capital costs in these representative examples. The amounts shown are the relevant payments for each dollar of asset cost.

\section{TABLE IV}

Down Payments Under Safe Harbor Leasing and Transfers to ACHIEve Equal Costs of Capital

\begin{tabular}{cccc}
\hline $\begin{array}{c}\text { Asset } \\
\begin{array}{c}\text { Depreciation } \\
\text { Rate }\end{array}\end{array}$ & $\begin{array}{c}\text { Down Payment } \\
\text { Under Five-Year } \\
\text { Lease }\end{array}$ & $\begin{array}{c}\text { Down Payment } \\
\text { Under Ten-Year } \\
\text { Lease }\end{array}$ & $\begin{array}{c}\text { Payment that } \\
\text { Equates Costs } \\
\text { of Capital }\end{array}$ \\
\hline .10 & .2089 & .2939 & .4417 \\
.15 & .2089 & .2939 & .3549 \\
\hline
\end{tabular}

The larger payments would be necessary to achieve equality of capital costs primarily because of the benefit from full deductibility of interest payments in a period of inflation.

Even apart from the effects of inflation, equality of capital costs could not be accomplished systematically by safe harbor leasing. Such equality would require rental payments to correspond with the lessor's actual capital costs, whereas a saleleaseback equates rental payments with payments for principal and interest on the fictional loan. As the Appendix shows, ${ }^{50}$ when rental payments are deferred relative to actual capital costs, a profitable lessor and a nontaxable lessee can benefit from the deferral because the lessee can invest the deferred rental payments at the pretax rather than the after-tax rate of return. Accordingly, the Treasury's requirement of market terms with respect to the loan in a sale-leaseback ${ }^{51}$ does not guarantee that the lessee will face the same cost of capital as will a profitable investor.

\section{B. Equality of Subsidies}

A second version of competitive neutrality might be that a loss company should receive the excess of the present value of tax reductions resulting from ACRS deductions and the ITC over the present value of tax reductions that result from de- 
ductions for economic depreciation. ${ }^{52}$ This goal would not put a loss company in the same after-tax position as a profitable company that can deduct interest payments, but it would grant both companies equal dollar benefits with respect to the ITC and ACRS. The assumption here might be that the relative after-tax positions of loss and profitable companies are acceptable, with the exception of changes brought about by adopting ACRS and the ITC instead of economic depreciation. Once again, calculations in the Appendix show that safe harbor leasing results in lessees' receiving an inappropriate amount of benefits in our two examples. But unlike the result that obtained when equality of capital costs was assumed to be the goal of competitive neutrality, the amount transferred by leasing is too large if an equal subsidy relative to economic depreciation is the goal of the program:

TABLE V

Down Payments Under Safe Harbor Leasing and Transfers to ACHIEve EQUal SUbSIDIES

\begin{tabular}{cccc}
\hline $\begin{array}{c}\text { Asset } \\
\begin{array}{c}\text { Depreciation } \\
\text { Rate }\end{array}\end{array}$ & $\begin{array}{c}\text { Down Payment } \\
\text { Under Five-Year } \\
\text { Lease }\end{array}$ & $\begin{array}{c}\text { Down Payment } \\
\text { Under Ten-Year } \\
\text { Lease }\end{array}$ & $\begin{array}{c}\text { Excess of ACRS and } \\
\text { ITC over Economic } \\
\text { Depreciation }\end{array}$ \\
\hline .10 & .2089 & .2939 & .1782 \\
.15 & .2089 & .2939 & .1352 \\
\hline
\end{tabular}

The payments under leasing are too large because the down payment equals the excess of the present value of tax reductions from ACRS deductions and the ITC over the present value of taxes on income in the amount of principal repayments, rather than over the present value of tax reductions resulting from economic depreciation. The amortization of loan principal is slower than the best approximations of economic depreciation, which are typically faster than straightline. ${ }^{53}$ Thus, the present value of principal repayments is

52 This version of competitive neutrality is itself subject to two interpretations, because the excess of the present value of ACRS deductions and ITC over the present value of economic depreciation can be determined using either the lessee's or the lessor's discount rate. A nontaxable lessee will discount cash flows at the pretax rate of return, while a profitable lessor will use the after-tax rate. Use of the lessee's rate to determine the subsidy could be justified on the theory that the lessee should be treated as if it received the same interest-free loan from ACRS that a profitable investor receives. Use of the lessor's rate could be justified on the theory that a profitable investor receives from ACRS the equivalent in present value of a cash grant and the lessee should therefore receive a payment of the same cash amount. Our computations are based upon the lessee's discount rate.

53 Hulten \& Wykoff, The Measurement of Economic Depreciation, in DEPRECIA- 
smaller than the present value of economic depreciation, and the resulting down payments are larger than payments computed with regard to economic depreciation.

\section{Equality of Additional Subsidy}

A third version of competitive neutrality might take as given the difference in pre-198 I tax treatment of profitable and loss companies and require only that loss companies receive the incremental subsidy enacted by the I98I Act. Because the ITC was in effect and depreciation for equipment was determined under the Asset Depreciation Range (ADR) before $\mathrm{I} 98 \mathrm{I},{ }^{54}$ the incremental subsidy is the additional acceleration of deductions under ACRS as compared with ADR. ${ }^{55}$ Under this view, the difference between safe harbor leasing and the appropriate benefit is even greater in our two examples than in the case described in Section B:

\section{TABLE VI}

Down Payments Under Safe Harbor Leasing and Transfers to ACHIEve Equal AdDitional Subsidies

\begin{tabular}{cccc}
\hline \hline $\begin{array}{c}\text { Asset } \\
\begin{array}{c}\text { Depreciation } \\
\text { Rate }\end{array}\end{array}$ & $\begin{array}{c}\text { Down Payment } \\
\text { Under Five-Year } \\
\text { Lease }\end{array}$ & $\begin{array}{c}\text { Down Payment } \\
\text { Under Ten-Year } \\
\text { Lease }\end{array}$ & $\begin{array}{c}\text { Excess of ACRS } \\
\text { over ADR }\end{array}$ \\
\hline .10 & .2089 & .2939 & .0380 \\
.15 & .2089 & .2939 & .0097 \\
\hline
\end{tabular}

\section{Summary}

The discussion in this Part is illustrative rather than exhaustive; other versions of competitive neutrality are conceivable. Equality of the subsidy might, for example, be measured in proportion to the amounts invested rather than in absolute after-tax dollars. Moreover, the foregoing discussion has fo-

tion, Inflation and the Taxation of Income from Capital 8I (C. Hulten ed. I98I).

54 See supra p. 1753.

55 Minor changes in the ITC to conform with enactment of ACRS are ignored in the interests of simplicity.

In Lubick \& Galper, The Defects of Safe Harbor Leasing and What to Do About Them, I4 TAX Notes 643,646 (Ig82), the authors assume that the subsidy element of current law is the excess of the present value of tax reductions from ACRS deductions and the ITC over the present value of tax reductions from ADR deductions. Because the ITC was in effect before the I98I Act, this formulation does not reflect only the incremental subsidy added by the Act. Nor does it reflect the total subsidy relative to economic depreciation. Rather, it appears to be an arbitrary specification of the subsidy using ADR as the nonsubsidy baseline for illustrative purposes. 
cused on identifying the appropriate payments for loss companies. Some versions of competitive neutrality might require different payments for other types of companies.

For our purposes, it is sufficient to conclude that none of the versions of competitive neutrality analyzed above leads to the results achieved by safe harbor leasing. However, further evaluation of leasing - such as a determination whether the benefits received by start-up and loss companies are too great or too small - is impossible because the precise form of competitive neutrality that is desired has not been articulated. Thus, leasing is consistent with its purpose only in the most general sense - it accomplishes some reduction of competitive inequality between profitable companies, on one hand, and start-up and loss companies, on the other. ${ }^{56}$ The conclusion that a more precise version of competitive neutrality must be formulated as a predicate to enactment of a coherent program is, of course, as applicable to refundability or to an explicit system of transferability as it is to leasing.

\section{Problems Caused by the Adoption of Leasing} RATHER THAN AN EXPLICIT PROGRAM OF TRANSFERABILITY

Although the Treasury and Congress were convinced that the benefits of ACRS and the ITC should be made transferable, explicit transferability was not adopted as part of the $\mathrm{Ig} 8 \mathrm{r}$ Act. Instead, pre-I $98 \mathrm{x}$ limitations on leasing transactions that were thought to inhibit transfers were eliminated, presumably on the theory that leasing would accomplish whatever would be accomplished by a program of explicit transferability.

Refundability of the relevant tax incentives is generally assumed to be the principal alternative to leasing, but it is also possible to design an explicit program of transferability that does not involve the fiction of leasing. ${ }^{57}$ One way to accomplish this result would be to create "tax instruments" that entitled the buyer of tax incentives to the full amount of ACRS deductions and the ITC. The instruments would also specify whatever further inclusions or deductions would be necessary to transfer only the net amount considered appropriate under the desired version of competitive neutrality. For example,

\footnotetext{
56 Under certain conditions, some versions of comparative neutrality would require a payment from the lessee to the lessor. See infra p. 1786 .

57 The Staff of the Joint Committee on Taxation states that neither refundability nor "pure sale of tax benefits" was adopted in I981 "primarily because of administrative difficulties in determining whether the property had been disposed of by the user in a transaction requiring recapture of investment tax credit or depreciation." Staff of the Joint Comm. on Tax'n, supra note 48, at J-8.
} 
under the second formulation above - equal excess of ACRS deductions and the ITC over economic depreciation - the purchaser of tax incentives would use the ITC and take ACRS deductions in accordance with the Code, but subsequently include in income amounts equal to the asset's economic depreciation, so that only the net benefit of the subsidy would be transferred. ${ }^{58}$ The seller of the tax incentives would deduct the asset's economic depreciation under a corresponding tax instrument.

This Part identifies some of the problems that follow from adopting leasing as a form of transferability, rather than simply enacting an explicit program of transferability.

\section{A. Inability to Achieve the Correct Result Under Any Version of Competitive Neutrality}

First, and most obviously, the statutory fiction of leasing inhibits reaching the correct results under any version of competitive neutrality. An explicit program of transferability requires a definition of the benefits to be transferred and, correspondingly, a definition of the baseline of competitive neutrality. The comparable issue under safe harbor leasing is framed as a determination of the terms appropriate for the fictional loan in a sale-leaseback. The Treasury's regulations on permissible loan terms - no balloon payments, a reasonable rate of interest, and amortization between straight-line and level-payment mortgage rates - are consistent with conceptualizing the transaction as a sale, loan, and leaseback, but those regulations do not result in future income inclusions (to reduce the value of ACRS deductions and the ITC) that are consistent with any version of competitive neutrality. ${ }^{59}$ The fiction of leasing thus dominates the purpose of the safe harbor in determining the amount of tax benefits that can be transferred.

Even if the Treasury were to adopt a particular version of competitive neutrality, implementation of that standard by regulation would arguably be inconsistent with the statutory mandate to treat the transaction as a lease. For example, permissible terms for the fictional lease could be artificially limited so that the present value of the resulting principal payments would equal the present value of economic depre-

58 Under this formulation, the profitable buyer of tax benefits would determine the maximum it would pay by using its own discount rate.

59 Temp. Treas. Reg. $\$_{5}$ c.168(f)(8)-7(b) (I 8 II). These provisions do establish an upper limit on the benefits that carrbe transferred from lessee to lessor. Whether that limit is appropriate depends on which version of competitive neutrality is appropriate. 
ciation. ${ }^{60}$ Even if such limitations were within the Treasury's broad authority to issue regulations for the safe harbor lease, ${ }^{61}$ a conclusion that is not obviously correct, such a rule would leave untouched a number of collateral problems created by the fiction of leasing.

\section{B. Subsequent Dispositions}

A complete program of transferability would need to specify the consequences of dispositions of both the recovery property and what we have called tax instruments. One possibility for tax incentives would be a no-deduction/no-inclusion system, under which the buyer of tax incentives could, for example, later sell its tax instrument and not include the sale proceeds in income. The transferee would take deductions and include income in accordance with the acquired tax instrument, but would not deduct the cost of the instrument itself. Because buyers would not have to bear the risk of being unable to use the purchased tax attributes in the future, such assignability of tax instruments would serve the purpose of the transferability program by increasing the price paid to initial sellers of tax attributes.

Disposition of the recovery property under this system might give rise to the same treatment that would apply to an owner-user of recovery property that does not sell the tax incentives. This result follows from the theory that the user that does sell tax incentives has, in effect, obtained the benefits of the incentives by creation of the tax instrument. Thus, a user of recovery property that first sold the benefits of ACRS and the ITC, and later sold the recovery property itself, might be subject to recapture of the transferred tax benefits if a comparable disposition by an owner-user that had not separated the tax attributes from the recovery property would cause recapture. ${ }^{62}$

60 Lubick and Galper suggest that this approach be taken with regard to the excess of the value of ACRS and the ITC over the value of ADR. See Lubick \& Galper, supra note 55 , at 649 .

61 I.R.C. $\& I 68(f)(8)(G)$ (West Supp. I982) provides broad authority for regulations "as may be necessary to carry out the purposes of this paragraph, including (but not limited to) regulations . . . which limit the aggregate amount of (and timing of) deductions and credits in respect of qualified leased property to the aggregate amount (and the timing) allowable without regard to this paragraph."

62 "Recapture" refers to the requirements that capital gain be taxed as ordinary income to offset prior depreciation deductions, I.R.C. $\$ \S 168,1245(a)(2)(E), 1245(a)(5)$, 1250 (West Supp. 1982), and that taxes be increased by the amount of previously received investment tax credits when section 38 property is disposed of before the end of the ITC holding period. Id. $\$ 47$. The additional tax that results from recapture is often called the "recapture tax." 
These suggestions regarding treatment of dispositions are intended to be just that - suggestions. A fully developed system of transferability might well include substantially different rules. For example, recapture of tax benefits by the buyer rather than by the user of the recovery property might be preferable if the user, perhaps because of loss carryovers, was not likely to have tax liability on disposition of the recovery property. ${ }^{63}$ The important conclusion for our purposes is that transferability itself requires neither the necessity of tying treatment of the tax instruments to treatment of the underlying property nor a continuing relationship between the buyer and seller of tax benefits. Under some versions of transferability, the buyer of tax benefits would have no interest in the seller's future tax situation, creditworthiness, or subsequent disposition of the recovery property. The results under safe harbor leasing are quite different.

I. Transfers by Safe Harbor Lessors. - Under the concept of tax ownership in safe harbor leasing, a lessor bears the burdens as well as the benefits of tax ownership. ${ }^{64}$ Accordingly, the regulations provide that a disposition by a lessor of its interest will be treated as a sale of the recovery property and will trigger recapture of ACRS deductions and the ITC. 65 This result is logical under the fiction of leasing, because the lessor is considered the owner of the property for tax purposes and dispositions by owners of recovery property generally give rise to recapture.

It is not obvious, however, that disposition by a buyer of a tax instrument - which is, after all, what a safe harbor lease actually is - should give rise to recapture of such benefits. As indicated above, the policy served by recapture might best be furthered by making disposition of recovery property by the user the only recapture event. Under an explicit program of transferability, this result could be accomplished by separating the consequences of disposition of the recovery property from the consequences of disposition of the tax instruments. The fiction of leasing prevents such separation, because the premise of the fiction is that there is only one asset, the recovery property, which has been divided into lessor and lessee interests. To put it somewhat differently, it is not obvious that a program of transferability for certain tax attri-

63 Another possibility would be to require payment of the recapture tax by the lessee without regard to the lessee's taxable income.

64 Remarks of John E. Chapoton, Assistant Secretary of the Treasury for Tax Policy, Before the Tax Society of New York University (Oct. 5, I98I) (on file in Harvard Law School Library) [hereinafter cited as Chapoton Remarks].

65 Temp. Treas. Reg. \$ 5c. I68(f)(8)-3(c), -8(d), -8(e) (Ig8I). 
butes of recovery property should require the simultaneous transfer of all other tax attributes of ownership.

2. Voluntary Transfers by Safe Harbor Lessees. - The regulations provide that a voluntary disposition of property by a lessee terminates treatment of the transaction as a lease and triggers recapture to the lessor unless the transferee consents "to take the property subject to the lease." 66 A consenting transferee deducts the excess of rent over interest payments (that is, the principal payments) just as the original lessee did. ${ }^{67}$ In effect, the user's interest in the recovery property is bound to the user's tax instrument, so that a buyer of the former must also take the latter.

Under an explicit program of transferability, a disposition of recovery property by the user might not require the transferee of the property to take the user's tax instrument as well. Nor would disposition of the user's tax instrument necessarily be prohibited if the user retained the recovery property. As indicated above, one possible treatment of early disposition of the recovery property would be to require the user to recapture tax benefits on the theory that it had obtained the value of those benefits on their transfer.

3. Credit Standing of a Safe Harbor Lessee. - If a program of transferability for tax benefits were unencumbered by leasing concepts, the credit standing of the seller of tax incentives would be of no concern to the buyer when the benefits were transferred for cash. The buyer would obtain only the ITC, ACRS deductions, and the future inclusions or deductions necessary to limit the transfer to the desired net subsidy. A subsequent bankruptcy of the seller would not affect the buyer.

Under the fiction of leasing, however, the creditworthiness of the lessee has been a major issue. ${ }^{68}$ An involuntary transfer of the recovery property in bankruptcy, or a similar transfer by a lessee to a creditor whose status is senior to the lessor's, logically (under the fiction of leasing) involves a transfer by the owner (lessor) of the property and therefore triggers the disposition consequences described above. ${ }^{69}$ If a lessor cannot be assured that future bankruptcy of the lessee will not terminate the lessor's interest, the lessor will discount the price

66 Temp. Treas. Reg. $\$ 5$ c. r68(f)(8)-2(a)(5), -8(d), -8(e) (198I), But see I27 Cong. REc. $\$ 8644$ (daily ed. July 28 , I98I) (statement of Senator Robert Dole, suggesting that sale by a lessee would have no tax consequences for a lessor).

67 Temp. Treas. Reg. \$ 5c.168(f)(8)-2(a)(7) (I98I).

68 Compare Temp. Treas. Reg. $\$ 5$ c.168(f)(8)-2(a)(5), -2(a)(6) (Nov. ro, I98I) (discussing consequences of lessee's bankruptcy), with Temp. Treas. Reg. $\$ 5$ c.168(f)(8)2(a)(5) (Oct. 20, Ig8I) (same).

${ }^{69}$ Chapoton Remarks, supra note 64 , at $\mathrm{II}$. 
it is willing to pay for future tax benefits by the risk that those benefits will not be available. The current solution in the regulations - continued characterization of a transaction as a lease if all secured lenders with interests in the property disclaim tax ownership with respect to the property ${ }^{70}$ - does not fully eliminate this risk. Indeed, it is arguable that a bankruptcy court could require a lessor to continue principal and interest payments to an insolvent lessee, even though the lessee was relieved of the obligation to make corresponding payments of rent to the lessor. ${ }^{71}$

\section{Audit Problems}

A program of refundability or transferability might create significant audit problems. Consider first a program of refundability. Would the Treasury simply issue checks to taxpayers on the traditional basis of self-assessment, given the possibility of fraudulent claims that recovery property had been purchased? Under a regime of transferability, on the other hand, how would the Internal Revenue Service audit a buyer's claim that the seller of tax incentives had purchased recovery property or that such property continued to qualify for the transferred tax benefits?

One possibility would be to put the burden of substantiation on the buyer of tax benefits, although this solution would require a continuing relationship between the buyer and the seller. Another possibility would be for the Internal Revenue Service to develop reporting and auditing mechanisms with respect to the selling company, which is, after all, the ultimate beneficiary of transferability. It might well be that audit problems are no more significant for start-up and loss companies than for profitable companies, for which the potential for fraud with regard to ACRS deductions and the ITC exists quite apart from transferability.

For our purposes it is sufficient to conclude that transferability might, but does not necessarily, make the buyer of tax incentives the Treasury's surrogate for audit purposes. Under safe harbor leasing, however, vesting federal tax ownership in lessors has necessarily made them Treasury surrogates for certain audit purposes. To protect themselves from fraudulent claims of investment in recovery property and from subsequent 
dispositions by lessees, lessors have required a variety of indemnities from lessees. ${ }^{72}$

\section{Other Structural Consequences}

There are, of course, other structural consequences that follow from leasing rather than transferability. They include the requirement that the at-risk rules of section $465^{73}$ be satisfied with respect to both the lessor and lessee, ${ }^{74}$ the realization by the lessor of an amount equal to the outstanding loan on the constructive transfer of the recovery property to the lessee that accompanies loss of safe harbor lease status, ${ }^{75}$ the allocation of costs by a transferee of the lessee among the note, leasehold interest, and option (if any) to buy the recovery property, ${ }^{76}$ and the prohibition of ITC sales separate from sales of ACRS deductions. ${ }^{77}$ A separate category of unnecessary consequences involves unintended results under taxes other than the federal income tax. States, for example, may regard the fictional sale and leaseback as real events for state sales and use tax purposes. Similarly, status as a fictional lessor-owner may affect the allocation of taxable income among states in which the allocation depends on a formula that includes the amount of the taxpayer's assets as a component.

\section{CONCLUSION}

This Article has not emphasized the defects of ACRS and the ITC apart from safe harbor leasing. It is therefore well to recall those defects in order to put the infirmities of leasing in context. As a tax reduction program, the combination of ACRS and the ITC is incoherent, given the continued deductibility of interest payments. As investment incentives, ACRS and the ITC are objectionable because their differential impact on industries and assets distorts investment decisions. ${ }^{78}$ Complete reform of the capital recovery provisions of the income tax should result in a neutral depreciation system and a less distorting form for investment subsidies. ${ }^{79} \mathrm{~A}$ program of

72 See Hahn, Transferring Deductions and Credits Under the Economic Recovery

Tax Act of 1981 - The Special Rule for Leases, 59 TAXes 963, 977-78 (1981).

${ }^{73}$ See I.R.C. $\S 465$ (West Supp. 1982).

74 Temp. Treas. Reg. $\$ 5$ C.I68(f)(8)-7(f) (I98I).

75 Temp. Treas. Reg. \$ 5 c. I68(f)(8)-8(d) (I98I).

${ }^{76}$ Temp. Treas. Reg. $\S 5$ c.I68(f)(8)-2(a)(7) (198I).

${ }^{77}$ See supra p. 1767 .

78 See Auerbach, supra note 3.

79 There is a growing literature discussing how such incentives might be designed. See, e.g., Auerbach, A Note on the Efficient Design of Investment Incentives, gI 
complete reform might also consider whether the net operating loss provisions are adequate, especially given the diminution in the value of carryovers caused by inflation. 80

If, however, ACRS and the ITC are to remain part of the tax system, and if net operating losses continue not to be refundable, there is a powerful argument for extending the ACRS and ITC subsidies to companies without current tax liability in order to avoid further distortions. This extension could be accomplished by either refundability or transferability of the relevant tax incentives. Under either type of program, the general principle of competitive neutrality must be specified in greater detail to determine the amount of tax benefits that should be made refundable or transferable. Safe harbor leasing currently transfers an amount of benefits that bears no particular relationship to any such specification.

Finally, even if one were to assume that transferability is preferable to refundability, there is no reason to effect transferability through the fiction of leasing. Indeed, the current statute and regulations suggest the opposite. The fiction has taken on a life of its own and has precluded consideration of alternative, and perhaps significantly better, resolutions of structural issues necessarily implicated by a program of transferability. While some of the results under leasing are plausible resolutions of structural issues, such as the consequences of disposition and the use of lessor involvement in lessee affairs to reduce the Internal Revenue Service's audit burden, other results, such as the amount of tax benefits transferred, plainly are not plausible resolutions. It seems likely that design of an innovative program of transferability, for which there are no developed models, could only be hindered by a requirement that the program conform to the dictates of the essentially irrelevant set of concepts involved in leasing.

\section{APPENDIX}

In this Appendix, we derive expressions for the size of the lease "down payment" corresponding to actual practice under safe harbor leasing (Section A), as well as the initial transfer to the lessee that would be appropriate:

ECON. J. $2 \mathrm{I} 7$ (I981); Bradford, Issues in the Design of Savings and Investment Incentives, in DEPRECIATION, INFLATION AND THE TAXATION OF INCOME FROM CAPITAL, supra note 53 , at 13 .

80 Carryovers could be made more valuable by annually increasing the amount carried over by a rate of interest or inflation, although such a provision could increase distortions that are attributable to the existence of the carryover. 
(I) to ensure that taxable and nontaxable companies are in equal competitive positions (have the same "user cost of capital") (Section B);

(2) to provide nontaxable firms with the value to them of the excess of the Accelerated Cost Recovery System (ACRS) deductions and the Investment Tax Credit (ITC) over economic depreciation (Section $\mathrm{C}$ ); and

(3) to provide nontaxable firms with the value to them of the excess of ACRS deductions and the ITC over credits and deductions available before passage of the Economic Recovery Tax Act of r98I under the Asset Depreciation Range (ADR) system (also Section C).

Because the structure of a lease has the greatest impact on firms that are not taxable over the term of the lease, we deal only with such firms. After developing the framework for analyzing safe harbor leasing, we apply the results from Sections $\mathrm{A}$ through $\mathrm{C}$ in a series of illustrative calculations in Section D.

\section{A. The Transfer Under Safe Harbor Leasing}

Under a typical safe harbor lease, a taxable corporate lessor purchases an asset from a lessee, using money "borrowed" from the lessee to cover all but a fraction $(d)$ of the initial price. Lessor and lessee agree to set rental payments equal to interest and principal payments by the lessor on the "loan." The lessor resells the asset to the lessee for effectively nothing after the "loan" has been repaid. ${ }^{81}$ Thus, the only money transferred between lessor and lessee is the initial "down payment," the amount corresponding to $d$. In exchange for this payment, the lessor acquires the asset's ACRS deductions and ITC and includes in annual income the value of rental payments net of interest payments - that is, the principal repayments. Thus, the amount a lessor will offer as a down payment $\left(d_{s h}\right)$ per dollar of lease property is

$$
d_{s h}=\left(k+\tau z_{l}\right)-\tau P V_{P}\left(\mathrm{I}-d_{s h}\right),
$$

where $k$ is the investment tax credit rate, $\tau$ the corporate tax rate, $z_{t}$ the present value of ACRS deductions per dollar of recovery property purchased (discounted at the lessor's aftertax discount rate), and $P V_{P}$ is the present value of principal repayments per dollar of level payment loan (discounted at the lessor's after-tax discount rate).

81 For a more detailed explanation of safe harbor leasing mechanics, see supra pp. I762-66. 
For a nontaxable lessee, the down payment is the only benefit received. Thus, changes in the terms of the lease that affect $P V_{P}$ will influence the amount of benefits the lessee realizes. A taxable lessee's benefits, however, are fixed solely by the value of ACRS deductions and the ITC. ${ }^{82}$

\section{B. Equal User Cost}

The user cost of capital is the constant rate of pretax cash flow that an asset must generate (for each dollar the asset is then worth) in order for its owner to make zero economic profits. ${ }^{83}$ The user cost is typically expressed as the ratio of this "zero profit" cash flow to asset cost. For a debt-financed investment, an owner realizes zero economic profits when pretax income is zero after interest payments are made. For an equity-financed investment, an owner realizes zero economic profits when after-tax earnings just equal the normal return on capital required by equity holders.

If an asset depreciates at an exponential rate $\delta$, the user cost to a taxable firm is

$$
c_{t}=\left(r_{t}+\delta-\pi\right)\left(\mathrm{I}-k-\tau z_{t}\right) /(\mathrm{I}-\tau),
$$

where $\pi$ is the annual rate of inflation in the asset's price and $r_{t}$ is the nominal after-tax corporate discount rate. For a nontaxable firm that sells its credits and deductions through a sale-leaseback, the user cost is

$$
c_{n}=\left(\gamma_{n}+\delta-\pi\right)(\mathrm{I}-d) .
$$

As before, $d$ is the down payment per dollar of capital purchased, and $r_{n}$ is the nontaxable firm's discount rate. (The down payment has the effect of a simple price reduction for the lessee.)

Taxable and nontaxable firms are in equal competitive positions only if they have the same user capital cost $\left(c_{t}=c_{n}\right)$. This result is achieved if the lease down payment $\left(d_{c}\right)$ satisfies the following equation:

$$
d_{c}=\mathrm{I}-\left(\frac{r_{t}+\delta-\pi}{r_{n}+\delta-\pi}\right)\left(\frac{\mathrm{I}-k-\tau z_{t}}{\mathrm{I}-\tau}\right) .
$$

82 If the lessee were taxable at the corporate rate, it would deduct from taxable income the net principal repayments. Thus, the total value of benefits received by the lessee would be $d+\tau P V(I-d)$, or (from equation (I)) the exact value of ACRS deductions and the ITC.

83 The user-cost-of-capital concept was originally formulated in Jorgenson, Capital Theory and Investment Behavior, AM: EcoN. REv., May 1963, at 247 (vol. 53 Papers and Proceedings). 
The value of $d_{c}$ thus depends on the discount rates of taxable and nontaxable firms; the discount rates, in turn, depend on the financing methods the firms use.

I. Debt Finance. - If taxable and nontaxable firms are debt financed at the margin, the discount rate $r_{n}$ equals $i$, the market interest rate, and the discount rate $r_{t}$ equals $i(I-\tau)$. Rearranging equation (4), and using these substitutions, we obtain

$$
d_{c}=\left(k+\tau z_{t}\right)-\tau \frac{(\delta-\pi)\left(\mathrm{I}-d_{c}\right)}{i(\mathrm{I}-\tau)+\delta-\pi} .
$$

Note that this expression for the transfer needed to equalize user costs of capital differs from the down payment made under safe harbor leasing in that the term for repayments, $P V_{P}$, has been replaced by the term $(\delta-\pi) /[i(\mathrm{I}-\tau)+\delta-\pi]$.

We now demonstrate that synchronizing implicit rental payments under the lease with "actual capital costs" (or the "spot rental rate") - the user cost of capital multiplied by the productive value of the asset - would result in a down payment that equalizes user costs for the taxable and nontaxable firm. Under such conditions, the annual rental payment under the lease $\left(L_{j}\right)$ in the $j$ th year after the asset's initial purchase would be

$$
L_{j}=c_{t}(\mathrm{I}-\delta+\pi)^{j} .
$$

(In nominal terms, $(\mathrm{I}-\delta+\pi)^{j}$ is the fraction of the asset's value remaining after $j$ years.) To convert this "real lease" into an arrangement with no periodic cash payments (as in a typical safe harbor leasing transaction), the lessor would borrow an initial fraction $(b)$ of the purchase price and repay the loan over time; thus, principal and interest payments in each year would equal the rental payments in equation (6). Annual principal $(P)$ and interest $(I)$ payments would change (declining if $\delta>\pi)$ at the same rate as rental payments and hence would be, respectively,

$$
P_{j}=(\delta-\pi)(\mathrm{I}-\delta+\pi)^{j} b
$$

and

$$
I_{j}=i(\mathrm{I}-\delta+\pi)^{i} b
$$

in year $j$. Setting $P_{j}+I_{j}$ equal to $L_{j}$, we obtain

$$
b=\frac{c_{t}}{i+\delta-\pi} .
$$


If the lessor also purchases the asset from the lessee, the down payment is

$$
d=\mathrm{I}-b=\mathrm{I}-\frac{c_{t}}{i+\delta-\pi},
$$

which is precisely the expression for $d_{c}$ in equation (4).

This analysis provides a useful starting point for determining the extent to which the down payment under actual safe harbor leasing deviates from such an equalization. For example, if in a safe harbor lease the lessee makes rental payments more slowly than a real lease would demand, the lessee can invest the deferred payments at the market interest rate (i). The lessor is made whole if paid $(\mathrm{I}+i(\mathrm{I}-\tau))$ per dollar of payments deferred. The difference, it per dollar of payments deferred, is a net gain to both the lessor and lessee (at the expense of corporate tax revenues) that can be divided between them. By deferring rental payments beyond spot rentals, the lessee can thus extract a premium for investing the lessor's funds at the pretax interest rate. The resulting down payment would be larger than that needed to equalize costs of capital.

2. Equity Finance. - If both taxable and nontaxable firms finance their investments with equity, then $r_{t}=r_{n}=\rho$, the equity-holders' nominal discount rate. Thus, equation (4), the expression for the transfer needed to equalize user costs of capital, may be written

$$
d_{c}=\left(k+\tau z_{l}\right)-\tau\left(\mathrm{I}-d_{c}\right) .
$$

A comparison of equation (II) with the safe harbor lease down payment in equation (I) suggests that $d_{c}$ must be less than $d_{s h}$, because a positive discount rate requires that the present value of principal repayments be less than one. Thus, it appears that the safe harbor lease gives nontaxable lessees a lower user cost of capital than taxable firms.

However, it is questionable whether this benefit should be attributed to the lease. Observe that the lessor, assumed here to use equity financing normally, finances most of the leased property with $d e b t$, and thereby receives interest deductions against the lease rental income. These interest deductions provide a financial advantage to the lessor that can be reflected in a premium that reduces the lessee's capital costs, as was the case in our earlier discussion of debt financing.

We now demonstrate that the safe harbor lease results in the appropriate transfer of benefits between equity-financed firms if two conditions hold. First, the financing decision must 
be considered separately from the lease itself. Second, the safe harbor lessor must treat the debt attributable to the safe harbor purchase as equivalent to any other debt.

To separate the issues of financing and lease structure, imagine that the lessor finances all property in the same manner, by equity finance, whether it be the leased property or property the lessor uses itself. For safe harbor leases, the lessor offsets the borrowing from the lessee by investing the implicit loan in some comparable form of debt, and thus in effect finances the lease property entirely from its own equity sources. Lease payments would be taxable to the lessor (the interest deductions would offset the interest income from the lessor's investment), and the value of the down payment would be

$$
d=\left(k+\tau z_{t}\right)-\tau P V_{L},
$$

where $P V_{L}$ is the present value of lease payments. For the lessor to break even, the present value of after-tax rental payments must equal the asset cost less ACRS deductions and the ITC, or

$$
(\mathrm{I}-\tau) P V_{L}=\mathrm{I}-k-\tau Z_{t} .
$$

Combining equations (I2) and (I3) yields

$$
d=\left(k+\tau z_{t}\right)-\tau(\mathrm{I}-d),
$$

which is precisely the expression for $d_{c}$, the amount needed to equalize user costs of capital, in equation ( $\mathrm{x} I$ ).

\section{Tax Benefits in Excess of Economic Depreciation or ADR}

Because the present value of economic depreciation is, from the lessee's viewpoint,

$$
z_{n}^{e}=\frac{\delta}{r_{n}+\delta-\pi}
$$

the down payment required to transfer ACRS benefits in excess of economic depreciation would be

$$
d_{e}=\left(k+\tau z_{n}\right)-\tau \frac{\delta}{r_{n}+\delta-\pi},
$$

where $z_{n}$ is the present value of ACRS deductions, discounted at $r_{n}$. In general, the value of $d_{e}$ will differ from that of $d_{c}{ }^{84}$

84 However, in the unlikely case in which (I) there is no inflation, (2) firms finance with debt, and (3) the combined effect of the ITC and ACRS may be approximated by immediate expensing, see supra pp. I754-55, for both lessor and lessee (that is, $k$ 
The comparison of tax benefits to ADR is similar to the comparison for economic depreciation. If $z_{n}^{a}$ is the present value of depreciation deductions, discounted at $r_{n}$ under ADR, then (assuming a full investment tax credit applied both before and after $\mathrm{I} 98 \mathrm{I}$ ) the transfer in excess of ADR would be 85

$$
d_{a}=\tau\left(z_{n}-z_{n}^{a}\right) \text {. }
$$

\section{Numerical Calculations}

To provide illustrative calculations, we assume that lessors purchasing tax incentives through safe harbor leasing finance their fictitious asset purchases by borrowing all but the "down payment" from the lessee. The interest deductibility on such debt becomes one of the additional benefits available from the safe harbor opportunity for firms that would otherwise finance with equity.

We assume a nominal market interest rate (or an after-tax equity discount rate, when equity finance is used) of fifteen percent and an inflation rate of eight percent. A fifteen percent interest rate is also used in the loan component of the safe harbor lease. The examples presented are for five-year and ten-year leases of two hypothetical assets in the five-year ACRS class, with exponential economic depreciation rates of . Io and .I5, respectively. These depreciation rates are typical for equipment in the five-year class. ${ }^{86}$ We assume corresponding ADR midpoint lives for those two assets of 12.5 and ro years, respectively, to represent rough averages of the different midpoint lives actually accorded such assets under ADR. 87 Actual depreciation under ADR is assumed to follow double-declining balance with an optimal switchover to straight line, based on the shortest lives in the ADR range for each asset (ten and eight years, respectively). Assets are assumed to be purchased at the end of a tax year.

As can be seen from Table VII, the current leasing program is either much too generous, or not generous enough, depending on how firms finance their investments and on what transfer of benefits was intended. Safe harbor leasing transfers more to nontaxable lessees than the difference between ACRS

$+\tau z=\tau$ ), then $d_{c}=d_{c}$. This result follows from a comparison of equations (5) and (I6).

85 If the investment tax credit is considered part of the subsidy to be delivered, see Lubick \& Galper, supra note 55 , then $k$ would be added to $d_{a}$.

86 See Hulten \& Wykoff, supra note 53, at 95-96.

87 Jorgenson \& Sullivan, Inflation and Corporate Capital Recovery, in DEPRECIATION, INFLATION AND THE TAXATION OF INCOME FROM CAPITAL, supra note 53, at I7r, I79 tables I \& 2. 
TABLE VII

Transfers Under Safe Harbor Leasing and Various ALTERNATIVES

\begin{tabular}{lcc}
\hline \hline \multicolumn{2}{c}{ Transfer $(d)$ per Dollar of Assets } \\
Safe Harbor Leasing & $\underline{\delta=.10}$ & $\underline{\delta}=.15$ \\
Debt Finance & .2089 & .2089 \\
$\quad$ Term of Lease $=5$ & .2939 & .2939 \\
$\quad$ Term of Lease $=10$ & .2164 & .2164 \\
Equity Finance & .3136 & .3136 \\
$\quad$ Term of Lease $=5$ & & \\
$\quad$ Term of Lease $=10$ & .4417 & .3549 \\
Equal User Cost & -.0207 & -.0207 \\
Debt Finance & .1782 & .1352 \\
Equity Finance & & \\
Excess Over Economic Depreciation & .1380 & .1097 \\
Excess Over ADR & .0380 & .0097 \\
$\quad$ ITC is part of subsidy & \\
ITC not part of subsidy & \\
\hline \hline
\end{tabular}

and ADR, and more than even the excess of ACRS and the ITC over economic depreciation. When debt financing is assumed, the transfer required to equalize user costs is larger than the down payment for safe harbor leasing. A higher down payment would be necessary to equalize user costs because the lease rental payments under our assumptions are accelerated relative to the spot rental rates (which are delayed because of the assumed eight percent inflation rate) that represent the true cost of using the equipment. Under equity financing, the down payment that equalizes user costs is slightly negative. With the assumed fifteen percent discount rate, the combined value of ACRS deductions and ITC is less than the value of expensing; the lessee's nontaxable status is worth more than the benefits of the ITC and ACRS. 